\title{
Editorial
}

\section{Old brands, new brands, neglected brands}

Having been a 'branding consultant' with Interbrand for over 20 years, I developed a deep curiosity as to what it would be like to sit on the other side of the table, that is to be a brand owner. This curiosity was, no doubt, tinged with the anxiety that, even though I might be pretty good at telling others how to develop and manage brands, I might not be so good at doing it myself.

So, over the course of the last three years, I have become a brand owner three times over:

- In 1995 I formed St. Peter's Brewery Company. My big idea is that, even though Britain has a huge brewing industry, it has no true international power brand, unlike Holland (Heineken), Singapore (Tiger) and even Jamaica (Red Stripe). I have set out, therefore, to create the international brand of English beer - St. Peter's. To date, four pubs have been opened to act as 'shop windows' for our beer and an ultra-modern brewery has been built at St. Peter's Hall, our 13th-century head office. We have also launched our new beer through Tesco. It comes in a $500 \mathrm{ml}$ oval, non-returnable bottle - a copy of one from Philadelphia dating from around 1770 . The response has been excellent and we believe we have a winner - but it is early days yet.

-- Then, in 1996, I and two others bought Plymouth Gin from Allied Domecq. Plymouth Gin was founded in 1793 and for generations was known as the gin of the Royal Navy but, in the 1960s and 1970s, as a result of vari- ous corporate mergers, it fell on hard times. This was particularly the case when, in the 1980 s, it was acquired by Allied Domecq and became subordinate to their main gin brand, Beefeater. Slowly the brand is being revived (sales have doubled this year, albeit from a low base) and our objective is that it should, within five years, be seen as one of a small group of elite English gins including Gordon's, Tanqueray, Beefeater and Bombay Sapphire.

- Finally, in 1997, I became an investor in, and Chairman of Caley's of Norwich, a once major chocolate manufacturer (Caley's Marching Chocolate, affectionately known as 'Marcho', was supplied to all British troops in World War I) which had been discontinued by its then owner, Rowntree-Macintosh, in the 1960s. In the 1990s, Nestle the new owners of Rowntree-Macintosh, decided to close the Norwich chocolate factory and three enterprising managers bought the Caley's trade mark and associated goodwill and resurrected the Caley's brand. There is enormous residual affection for the brand, especially in East Anglia, though we plan to extend the brand nationally within the year.

But what have I learned about brands and branding now I have crossed to the other side of the table? In fact, there have been no profound revelations, at least not yet. However, my new role has certainly reinforced certain beliefs and provided me with some deeper insights. I would list my 'top five' among these as follows: 
- More than ever, I realise that brands must have a real point of difference in order to succeed. Consumers and retailers are bombarded with new brands but most are pretty much undifferentiated from those that are already around, and provide customers and retailers with no reason to switch. (St. Peter's bottled beers are highly differentiated, mainly due to the lovely oval bottle but we are having to sharpen up the positioning of both Plymouth Gin and Caley's chocolate as assertions of heritage and quality are insufficient, on their own, truly to set these fine products apart from the competition.)

- Brands have an extraordinary inertia once they are big and established they take a lot of messing up, but once they have lost momentum (as with Plymouth Gin and Caley's) it takes a lot to get them going again. (Fortunately it is this phenomenon that makes good brands so valuable and that, in part at least, explains my interest in brands.)

- The only way to manage a brand is intensely, passionately and single-mindedly.

-. In Britain we have been astonishingly profligate and wasteful of our national brand inheritance. Thousands of fine brands have been shelved or destroyed
(Plymouth Gin and Caley's are only two examples from many) due to corporate mergers and the prevailing view among brand owners that they would sooner destroy a brand than risk it becoming a competitor.

- Those of us involved in brands and branding like to think that 'brand-centricity' is normal. In fact, it is not so. Most people and organisations have not the slightest idea what a brand is and think and act almost exclusively in product terms. Even apparently sophisticated companies see branding as a labelling exercise and believe that marketing is the same as advertising.

And, on the 'non-brand related' side what has really come home to me is the absolutely critical importance of developing a competent, creative, hard-working, positive, agreeable management team — I had such a team at Interbrand (they are all still there) and there are now excellent management teams in place at St. Peter's Brewery, Plymouth Gin and Caley's of Norwich. This has taken some time to achieve and has not always been easy.

John M. Murphy Editorial Board 